\title{
Van opsluitwet naar zorgwet - en breder
}

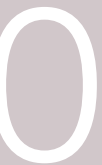

ngeveer anderhalf jaar geleden deed ik in een interview in Sociaal Bestek de oproep om haast te maken met de invoering van de Wet verplichte ggz (Wvggz). Het is naar mijn idee een belangrijke schakel voor een succesvolle aanpak van de problematiek van personen met verward gedrag. Deze wet biedt immers mogelijkheden om het grijze gebied tussen geen behandeling en gedwongen intramurale behandeling te verkleinen, door bijvoorbeeld verplichte zorg buiten een instelling mogelijk te maken. De wet zal per 1 januari 2020 in werking treden, dat is een stap vooruit. Eindelijk krijgt de familie meer mogelijkheden. Echter, de problematiek rond verward gedrag is veel breder dan alleen ggz. In veel regio's is de aanpak van de problematiek rond personen met verward gedrag inmiddels voortvarend opgepakt. Landelijk is een speciaal schakelteam actief dat regio's bezoekt, aanbevelingen doet en er voor zorgt dat goede ideeën worden gedeeld.

\section{Partiners}

In Friesland hebben we in samenwerking met verschillende partners de afgelopen periode belangrijke stappen gezet. Bijvoorbeeld via een viertal veelbelovende pilots. Pilots waar stuk voor stuk krachten worden gebundeld en oplossingen zijn bedacht voor passende zorg en ondersteuning.

De pilot Rapid Responder GGZ: de samenwerking tussen Regionale Ambulancevoorziening Fryslân, GGZ Friesland, Zorgverzekeraar Fryslan en Sociaal Domein Fryslân heeft geleid tot een pilot voor alternatief vervoer en beoordeling. De RR GGZ bestaat uit vier sociaal psychiatrisch verpleegkundigen en vier chauffeurs in een neutrale bus. De inzet van dit team leidt in meer dan de helft van de acute gevallen tot de-escalatie ter plaatse in plaats van vervoer naar het cellencomplex.

De crisisbeoordelingskamer: de pilot rond de crisisbeoordelingskamer hangt samen met de pilot vervoer. In de samenwerking tussen ggz, Politie, GGD en Sociaal Domein Fryslân is een speciale ruimte bij de Eerste Hulp Post in ziekenhuis MCL, waar in relatieve rust de beoordeling kan plaatsvinden. Het aantal beoordelingen in de politiecel, vaak erg belastend voor de betrokkene, kan hierdoor ook worden teruggebracht.

ACT-team (Assertive Community Treatment): dit betreft een bemoeizorgteam bij de nachtopvang in Leeuwarden. Een groep personen uit de hele provincie met complexe problematiek, (een combinatie van) een psychische stoornis, verslaving en in veel gevallen ook een verstandelijke beperking, maakt steeds vaker gebruik van de nachtopvang waardoor deze overbezet en overbelast raakt. De samenwerking tussen ggz, VNN en Zienn leidt er toe dat meer personen met complexe problematiek worden toegeleid naar zorg en huisvesting.

Onconventioneel wonen: deze pilot draait om het huisvesten van personen die door hun gedrag en ziektebeeld nergens meer een plek hebben. Het gaat hierbij bijvoorbeeld om beschikbaar stellen van mobiele wooncontainers. Dit betreft een samenwerking tussen een aantal Friese gemeenten en woningcorporaties.

\section{Stellig}

We hopen de toename van de problematiek die de afgelopen jaren zichtbaar was, een halt toe te hebben geroepen. Een gezamenlijk gedragen en integrale aanpak van lokale en regionale partners is essentieel. De Wvggz zal ons nog een stap verder brengen, zo is mijn stellige overtuiging. Dat is van groot belang: voor de maatschappij, voor de familie en zeker niet in de laatste plaats voor de betrokkene zelf. 